\title{
Xanthofulvin, a Novel Semaphorin Inhibitor Produced by a Strain of Penicillium
}

\author{
Kazuo Kumagai*, Nobuo Hosotani, KaOru KiKuchi ${ }^{\dagger}$, \\ TORU KIMURA ${ }^{\dagger}$ and IKUTARO SAJI
}

\begin{abstract}
Exploratory Research Group, Research Division, Sumitomo Pharmaceuticals Co., Ltd., 4-2-1 Takatsukasa, Takarazuka, Hyogo 665-0051, Japan

${ }^{\dagger}$ Genomic Science Laboratories, Research Division, Sumitomo Pharmaceuticals Co., Ltd., 3-1-98 Kasugadenaka, Konohana-ku, Osaka 554-0022, Japan
\end{abstract}

(Received for publication January 31, 2003)

\begin{abstract}
A new semaphorin inhibitor xanthofulvin was isolated from the cultured broth of a fungus Penicillium sp. SPF-3059 along with a known compound vinaxanthone by solvent extraction and bioassay-guided fractionation. The tautomeric structure of xanthofulvin was determined by spectroscopic analyses. The two compounds exhibited significant semaphorin inhibitory activity with $\mathrm{IC}_{50}$ values of 0.09 and $0.1 \mu \mathrm{g} / \mathrm{ml}$, respectively, in semaphorin $3 \mathrm{~A}$-induced growth cone collapse assay using cultured chick dorsal root ganglia neurons.
\end{abstract}

Semaphorins are a family of soluble and membranebound proteins that have been shown to function as regulatory factors during neuronal development of the central and peripheral nervous systems. Most semaphorins act as a chemorepellent on a wide variety of axons, thus they are thought to be repulsive guidance cues to axons ${ }^{1)}$. To date more than 20 semaphorins have been identified and classified into 8 classes $^{2)}$. Semaphorin 3A (Sema3A), a soluble and the prototype semaphorin, has been shown to cause collapse of neurite growth cones, resulting in inhibition of neuronal outgrowth in vitro and in vivo ${ }^{3,4)}$. In the mature mammalian central nervous system, expression of semaphorins elevates after neuronal injury ${ }^{5}$. Once injured, axons can hardly regenerate in the presence of these repulsive proteins. Therefore we consider that inhibitors of semaphorins may be of potential use as drugs for the treatment of traumatic neuronal injury.

In search for semaphorin inhibitors from microorganisms, we isolated two active compounds from the cultured broth of a fungal strain SPF-3059. The compounds were identified as a new compound xanthofulvin (1) and previously reported vinaxanthone $e^{6,7)}$ (2) (Fig. 1). Although both compounds were first isolated in the early 1990s, the former has not yet been reported in publication. This is the first report describing xanthofulvin in detail. In this paper we describe the taxonomy of the

Fig. 1. Structures of xanthofulvin (1) and vinaxanthone (2).

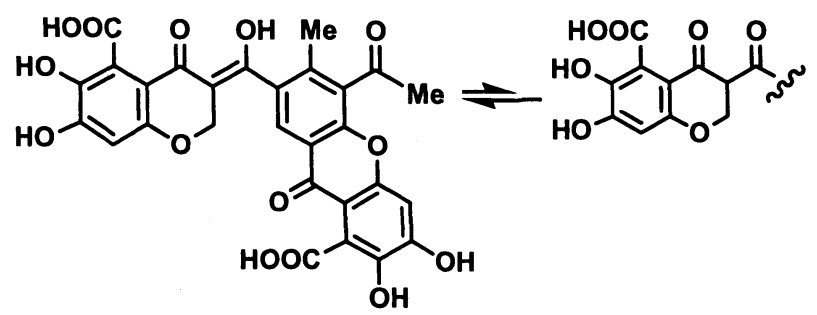

1<smiles>CC(=O)c1c(C(=O)[N+](=O)[O-])cc2oc3cc(O)c(O)c(C(=O)O)c3c(=O)c2c1Cc1coc2cc(O)c(O)c(O)c2c1=O</smiles>

2

\footnotetext{
* Corresponding author: kumagai@sumitomopharm.co.jp
} 
producing organism, fermentation, isolation, structure elucidation of xanthofulvin and semaphorin inhibitory activity of these two compounds.

\section{Materials and Methods}

\section{General}

UV spectra were recorded on a Hitachi U-2000 spectrophotometer. IR spectra were recorded on a PerkinElmer 1600 series FT-IR spectrometer. FAB-MS spectra were obtained on a JEOL JMS-SX102A spectrometer. NMR spectra were recorded on a JEOL JNM $\alpha-500$ spectrometer and the chemical shifts are given in ppm referenced to DMSO- $d_{6}$ as $2.49 \mathrm{ppm}\left({ }^{1} \mathrm{H}\right)$ and $39.5 \mathrm{ppm}$ $\left({ }^{13} \mathrm{C}\right)$.

\section{Microorganism}

The fungal strain SPF-3059 was isolated from a soil sample collected in Osaka, Japan. The strain has been deposited at the International Patent Organism Depositary, the National Institute of Advanced Industrial Science and Technology, Japan under the accession number FERM P17766.

\section{Taxonomy}

Taxonomic studies of the strain SPF-3059 were done according to the method of PITT $^{8)}$. For the evaluation of cultural characteristics, Czapek yeast extract agar (CYA, $\mathrm{K}_{2} \mathrm{HPO}_{4} 0.1 \%$, yeast extract $0.5 \%$, sucrose $3 \%, \mathrm{NaNO}_{3}$ $0.3 \%, \mathrm{KCl} 0.05 \%, \mathrm{MgSO}_{4} \cdot 7 \mathrm{H}_{2} \mathrm{O} 0.05 \%, \mathrm{FeSO}_{4} \cdot 7 \mathrm{H}_{2} \mathrm{O}$ $0.001 \%$, agar $1.5 \%$ ), malt extract agar (MEA, malt extract $2 \%$, peptone $0.1 \%$, glucose $2 \%$, agar $1.5 \%$ ), $25 \%$ glycerol nitrate agar $\left(\mathrm{G} 25 \mathrm{~N}, \mathrm{~K}_{2} \mathrm{HPO}_{4} 0.075 \%\right.$, yeast extract $0.37 \%$, glycerol $25 \%, \mathrm{NaNO}_{3} 0.23 \%, \mathrm{KCl} 0.038 \%, \mathrm{MgSO}_{4} \cdot 7 \mathrm{H}_{2} \mathrm{O}$ $0.038 \%, \mathrm{FeSO}_{4} \cdot 7 \mathrm{H}_{2} \mathrm{O} 0.0008 \%$, agar $1.2 \%$ ), yeast extract soluble starch agar (yeast extract $0.2 \%$, soluble starch $1 \%$, agar $1.5 \%$ ), potato dextrose agar (PDA, Nihon Pharmaceutical) and ISP medium No. 3 (Nihon Pharmaceutical) were used. Fine morphological structures were observed using a Hitachi S-800 scanning electron microscope. Color names were determined by using the Color Tone Manual $1^{9}$.

\section{Fermentation}

A slant culture of the strain SPF-3059 was inoculated into a $500-\mathrm{ml}$ Sakaguchi flask containing $75 \mathrm{ml}$ of liquid medium consisted of glucose $2 \%$, sucrose $5 \%$, cottonseed flour $2 \%, \mathrm{NaNO}_{3} \mathrm{0.1} \%$, L-histidine $0.1 \%, \mathrm{~K}_{2} \mathrm{HPO}_{4} 0.05 \%$, $\mathrm{KCl} 0.07 \%, \mathrm{MgSO}_{4} \cdot 7 \mathrm{H}_{2} \mathrm{O} 0.0014 \%, \mathrm{pH} 7.0$, and cultured for 5 days at $27^{\circ} \mathrm{C}$ with reciprocal shaking at $130 \mathrm{rpm}$. An aliquot of $6 \mathrm{ml}$ of this seed culture was transferred into 2-liter Sakaguchi flasks containing $300 \mathrm{ml}$ of the same medium, and cultured at $27^{\circ} \mathrm{C}$ with reciprocal shaking at $110 \mathrm{rpm}$.

\section{HPLC Analysis}

The cultured broth $(10 \mathrm{ml})$ was centrifuged at $3,000 \mathrm{rpm}$ for 5 minutes, then the supernatant and the cell cake were extracted with $10 \mathrm{ml}$ of formic acid-EtOAc (1:99), and $\mathrm{Me}_{2} \mathrm{CO}$, respectively. The extracts were evaporated to dryness under reduced pressure, and the residues were dissolved in $1 \mathrm{ml}$ of $\mathrm{MeOH}$. Samples $(20 \mu \mathrm{l})$ were analyzed by reversed-phase HPLC using a Wakopak WakosilII5C18RS column $(4.6 \times 150 \mathrm{~mm})$ with $1 \%$ aqueous formic acid - $\mathrm{MeOH}$ (80:20 to $30: 70$ in 77 minutes) at a flow rate of $1.3 \mathrm{ml} / \mathrm{minute}$, and detection of UV absorption at $260 \mathrm{~nm}$. Compounds 1 and 2 were eluted at 37.5 and 28.0 minutes, respectively.

\section{Preparation of Sema3A}

The cDNA of mouse Sema3 $\mathrm{A}^{10)}$ was cloned into $\operatorname{pUCSR} \alpha$ expression vector ${ }^{11)}$ and transiently expressed in COS-7 cells using FuGene6 transfection reagent (Roche Diagnostics). The cultured conditioned medium was used as recombinant Sema3A without further purification ${ }^{12)}$.

\section{Semaphorin Inhibitory Assay}

Dorsal root ganglia (DRG) explants excised from E7 chick embryos were cultured in F12 medium supplemented with $10 \%$ fetal bovine serum (Gibco BRL) and $20 \mathrm{ng} / \mathrm{ml}$ nerve growth factor (Promega) at $37^{\circ} \mathrm{C}$ for 20 hours using 96-well culture plates pre-coated with poly-L-lysine and laminin. Assay samples were added to the wells 1 hour before addition of the recombinant mouse Sema3A at a final concentration of $3 \mathrm{U} / \mathrm{ml}$ to induce complete collapse of growth cones $(1 \mathrm{U} / \mathrm{ml}$ of Sema3A is defined as the amount required to collapse $50 \%$ of DRG growth cones) $)^{3)}$. One hour after addition of Sema3A, wells were fixed with $1 \%$ glutaraldehyde, then the numbers of collapsed and uncollapsed growth cones were counted under a light microscope. In each well at least 100 growth cones were counted.

\section{Results}

Taxonomy

Colonies of the strain SPF-3059 grown on CYA, MEA, PDA and yeast extract - soluble starch agar at $25^{\circ} \mathrm{C}$ for 7 
Fig. 2. Scanning electron micrograph of strain SPF-3059 grown on ISP medium No. 3 at $25^{\circ} \mathrm{C}$ for 14 days.

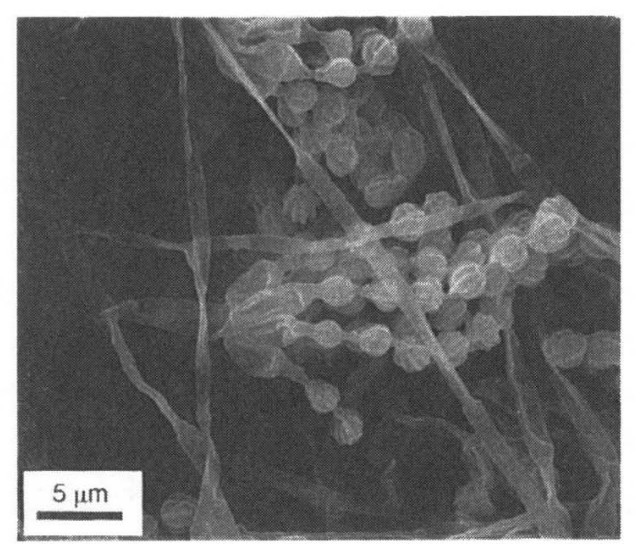

days were white and floccose with a diameter of $9 \sim 11 \mathrm{~mm}$. The reverse side color was pale yellow. Colonies on $\mathrm{G} 25 \mathrm{~N}$ were white and floccose with a diameter of $3 \sim 4 \mathrm{~mm}$. The reverse side color was pale yellow. Neither soluble pigment nor sporulation was observed on these agar media even after one month of incubation. On the contrary, on ISP medium No. 3, one of actinomycete identification agar media, unexpected sporulation was observed in 7 days. Colonies grown on ISP medium No. 3 at $25^{\circ} \mathrm{C}$ for 14 days were beige to grayish green and floccose with a diameter of 1 $1 \sim 12 \mathrm{~mm}$. The reverse side color was beige to light grayish green due to good sporulation. Conidiophores were formed from substrate and aerial hyphae, and penicillia were monoverticillate (Fig. 2). Stipes were smooth-walled and $5 \sim 20 \mu \mathrm{m}$ long. Phialides were ampulliform and $3 \sim 5 \mu \mathrm{m}$ long. Conidia were globose to subglobose, $2 \sim 2.3 \mu \mathrm{m}$ in diameter with striated surface. Teleomorph was not observed. From the above characteristics, the strain SPF-3059 was identified as a member of the genus Penicillium and named Penicillium sp. SPF-3059.

\section{Isolation}

In shaking culture, productivity of $\mathbf{1}$ reached maximum at day 8 of fermentation (Fig. 3). So the cultured broth (3 liters) was harvested at day 8 and centrifuged at $10,000 \mathrm{~g}$ for 10 minutes at $4^{\circ} \mathrm{C}$. The cell cake was extracted with 3 liters of acetone and evaporated under reduced pressure. The resulting aqueous solution was extracted with 1 liter of formic acid-ethyl acetate $(1: 99)$. The culture supernatant
Fig. 3. Time course of production of xanthofulvin (1) and vinaxanthone (2) by Penicillium sp. SPF3059 .

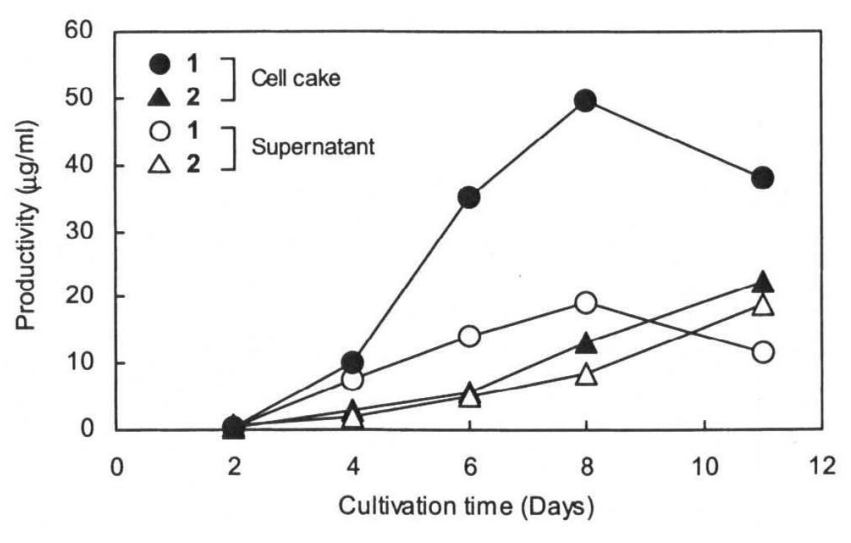

was extracted with 3 liters of formic acid-ethyl acetate (1:99). Both acidic ethyl acetate extracts were combined and concentrated to dryness under reduced pressure to yield $10.4 \mathrm{~g}$ of oily material. The material was dissolved in $100 \mathrm{ml}$ of methanol and applied to a column of Sephadex LH-20 (Amersham Biosciences), and the column was eluted with methanol. Active fractions (2.6 g) were collected, applied to a column of Toyopearl HW-40F (Tosoh) and eluted with methanol. Active fractions (1.6 g) were pooled and injected into preparative HPLC equipped with Wakopak Wakosil-II5C18HG-Prep columns $(30 \times 100+30 \times 250 \mathrm{~mm})$. The elution was performed with $1 \%$ aqueous formic acid $-\mathrm{MeOH}(55: 45$ to $25: 75$ in 120 minutes) at a flow rate of $20 \mathrm{ml} /$ minute and detection of UV absorption at $260 \mathrm{~nm}$. Two active substances were obtained and finally purified by re-chromatography using the HPLC to give $\mathbf{1}(64 \mathrm{mg})$ and $\mathbf{2}(34 \mathrm{mg})$ as yellow powders.

\section{Structure Elucidation}

The physico-chemical properties of $\mathbf{1}$ and $\mathbf{2}$ are summarized in Table 1. Similarity in these data suggested that they were structurally related. Compound $\mathbf{2}$ was identified as a known compound vinaxanthone ${ }^{6)}$ by its UV, IR, MS and ${ }^{1} \mathrm{H}$ and ${ }^{13} \mathrm{C}$ NMR spectral data. The ${ }^{13} \mathrm{C}-{ }^{1} \mathrm{H}$ long-range couplings of ${ }^{2} J,{ }^{3} J$ and ${ }^{4} J$ observed in the HMBC experiments supported the identity of $\mathbf{2}$ and were helpful in determining the structure of 1 (Fig. 4).

The molecular formula of $\mathbf{1}$ was established as $\mathrm{C}_{28} \mathrm{H}_{18} \mathrm{O}_{14}$ by HRFAB-MS, differing from that of $\mathbf{2}$ by the addition of 
Table 1. Physico-chemical properties of $\mathbf{1}$ and $\mathbf{2}$

\begin{tabular}{lll}
\hline & \multicolumn{1}{c}{1} & \multicolumn{1}{c}{2} \\
\hline Appearance & Yellow powder & Pale yellow powder \\
Molecular formula & $\mathrm{C}_{28} \mathrm{H}_{18} \mathrm{O}_{14}$ & $\mathrm{C}_{28} \mathrm{H}_{16} \mathrm{O}_{14}$ \\
FAB-MS $(m / z)$ & $579(\mathrm{M}+\mathrm{H})^{+}, 577(\mathrm{M}-\mathrm{H})^{-}$ & $577(\mathrm{M}+\mathrm{H})^{+}, 575(\mathrm{M}-\mathrm{H})^{-}$ \\
HRFAB-MS $(m / z)$ & & \\
$\quad$ Found: & $579.0772(\mathrm{M}+\mathrm{H})^{+}$ & $577.0618(\dot{\mathrm{M}}+\mathrm{H})^{+}$ \\
$\quad$ Calcd.: & 579.0776 & 577.0619 \\
UV $\lambda_{\max } \mathrm{nm}(\varepsilon, \mathrm{MeOH})$ & $241(31,600), 315(23,400)$, & $229(35,800), 284(22,600)$, \\
& $365(16,500)$ & $322(21,000)$ \\
IR $v_{\max }(\mathrm{KBr}) \mathrm{cm}^{-1}$ & $3330,1700,1620,1570$, & $3260,1684,1626,1567$, \\
Solubility & 1460,1270 & 1467,1288 \\
$\quad$ Soluble: & & \\
$\quad$ Slightly soluble: & $\mathrm{DMSO}, \mathrm{Tetrahydrofuran}$ & $\mathrm{DMSO}$, Tetrahydrofuran \\
$\quad$ Insoluble: & $\mathrm{MeOH}$ & $\mathrm{MeOH}$ \\
& $\mathrm{H}_{2} \mathrm{O}, n$-Hexane & $\mathrm{H}_{2} \mathrm{O}, n$-Hexane \\
\hline
\end{tabular}

Table 2. $\quad{ }^{1} \mathrm{H}$ and ${ }^{13} \mathrm{C}$ NMR chemical shifts of $\mathbf{1}$ (tautomers $\mathbf{1 a}$ and $\mathbf{1 b}$ ) and $\mathbf{2}$ in DMSO- $d_{6}$.

\begin{tabular}{|c|c|c|c|c|c|c|}
\hline \multirow{2}{*}{ No. } & \multicolumn{2}{|c|}{$1 \mathbf{a}$} & \multicolumn{2}{|c|}{$1 \mathrm{~b}$} & \multicolumn{2}{|c|}{2} \\
\hline & ${ }^{13} \mathrm{C}$ & ${ }^{1} \mathrm{H}(J=\mathrm{Hz})$ & ${ }^{13} \mathrm{C}$ & ${ }^{1} \mathrm{H}(J=\mathrm{Hz})$ & ${ }^{13} \mathrm{C}$ & ${ }^{1} \mathrm{H}(J=\mathrm{Hz})$ \\
\hline 1 & 120.6 & & 120.6 & & 119.6 & \\
\hline 2 & 140.7 & & 140.8 & & 141.2 & \\
\hline 3 & 153.8 & & 153.8 & & 154.5 & \\
\hline 4 & 102.3 & $6.91(1 \mathrm{H}, \mathrm{s})$ & 102.3 & $6.91(1 \mathrm{H}, \mathrm{s})$ & 102.3 & $6.93(1 \mathrm{H}, \mathrm{s})$ \\
\hline $4 a$ & 150.2 & & 150.1 & & 150.4 & \\
\hline 5 & 132.4 & & 132.4 & & 133.4 & \\
\hline 6 & 138.1 & & 139.1 & & 132.5 & \\
\hline 7 & 129.9 & & 134.9 & & 136.2 & \\
\hline 8 & 125.8 & $7.91(1 \mathrm{H}, \mathrm{brs})$ & 127.7 & $8.52(1 \mathrm{H}, \mathrm{s})$ & 126.3 & $8.53(1 \mathrm{H}, \mathrm{s})$ \\
\hline $8 \mathrm{a}$ & 118.5 & & 118.2 & & 120.3 & \\
\hline 9 & 172.8 & & 172.7 & & 172.5 & \\
\hline $9 a$ & 110.1 & & 110.1 & & 109.9 & \\
\hline $10 \mathrm{a}$ & 152.2 & & 152.2 & & 152.1 & \\
\hline 11 & 167.5 & & 167.6 & & 167.5 & \\
\hline 12 & 202.7 & & 202.9 & & 201.1 & \\
\hline 13 & 32.4 & $2.69(3 \mathrm{H}, \mathrm{s})$ & 32.4 & $2.67(3 \mathrm{H}, \mathrm{s})$ & 32.1 & $2.55(3 \mathrm{H}, \mathrm{s})$ \\
\hline 14 & 16.5 & $2.28(3 \mathrm{H}, \mathrm{brs})$ & 17.0 & $2.28(3 \mathrm{H}, \mathrm{s})$ & 199.1 & \\
\hline 15 & 172.7 & & 199.1 & & 29.1 & $2.53(3 \mathrm{H}, \mathrm{s})$ \\
\hline $2^{\prime}$ & 65.7 & $4.68(2 \mathrm{H}, \mathrm{brs})$ & 68.0 & $\begin{array}{l}4.61(1 \mathrm{H}, \mathrm{dd}, 11.6,9.2) \\
4.71(1 \mathrm{H}, \mathrm{dd}, 11.6,4.9)\end{array}$ & 152.7 & $8.17(1 \mathrm{H}, \mathrm{s})$ \\
\hline $3^{\prime}$ & 104.2 & & 56.2 & $5.02(1 \mathrm{H}, \mathrm{dd}, 9.2,4.9)$ & 120.9 & \\
\hline $4^{\prime}$ & 183.7 & & 186.3 & & 172.9 & \\
\hline $4^{\prime} \mathrm{a}$ & 110.1 & & 108.8 & & 112.4 & \\
\hline $5^{\prime}$ & 120.6 & & 122.2 & & 119.8 & \\
\hline $6^{\prime}$ & 137.6 & & 137.6 & & 141.7 & \\
\hline $7^{\prime}$ & 154.5 & & 154.5 & & 152.7 & \\
\hline $8^{\prime}$ & 102.3 & $6.40(1 \mathrm{H}, \mathrm{s})$ & 102.3 & $6.40(1 \mathrm{H}, \mathrm{s})$ & 102.3 & $6.96(1 \mathrm{H}, \mathrm{s})$ \\
\hline $8 a^{\prime}$ & 156.3 & & 156.3 & & 150.8 & \\
\hline $9^{\prime}$ & 167.5 & & 167.6 & & 167.4 & \\
\hline $3-\mathrm{OH}$ & & $9.30^{a}(1 \mathrm{H}, \mathrm{br} \mathrm{s})$ & & $\mathrm{ND}^{c}$ & & $9.52^{d}(1 \mathrm{H}, \mathrm{br} \mathrm{s})$ \\
\hline $7^{\prime}-\mathrm{OH}$ & & $8.70^{a}(1 \mathrm{H}, \mathrm{br} \mathrm{s})$ & & ND & & $9.52^{d}(1 \mathrm{H}, \mathrm{br} \mathrm{s})$ \\
\hline $2-\mathrm{OH}$ & & $11.61^{b}(1 \mathrm{H}$, br s $)$ & & ND & & $11.53^{e}(1 \mathrm{H}, \mathrm{br} \mathrm{s})$ \\
\hline 6'-OH & & $11.22^{b}(1 \mathrm{H}, \mathrm{br} \mathrm{s})$ & & ND & & $11.53^{e}(1 \mathrm{H}, \mathrm{br} \mathrm{s})$ \\
\hline $11,9^{\prime}-\mathrm{OH}$ & & $12.71(2 \mathrm{H}, \mathrm{br} \mathrm{s})$ & & ND & & $12.62(2 \mathrm{H}, \mathrm{br} \mathrm{s})$ \\
\hline $15-\mathrm{OH}$ & & ND & & & & \\
\hline
\end{tabular}

${ }^{a, b}$ Assignments may be interchanged. ${ }^{c}$ Not determined because signals were too broad to determine chemical shifts. ${ }^{d, e}$ Overlapped. 
Fig. 4. ${ }^{1} \mathrm{H}-{ }^{1} \mathrm{H}$ COSY and $\mathrm{HMBC}$ correlations observed in $\mathbf{1 a}, \mathbf{1 b}$ and $\mathbf{2}$.

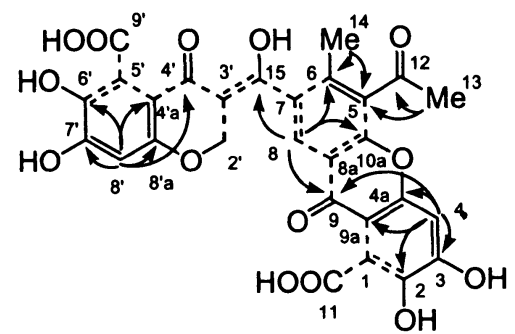

$1 \mathrm{a}$

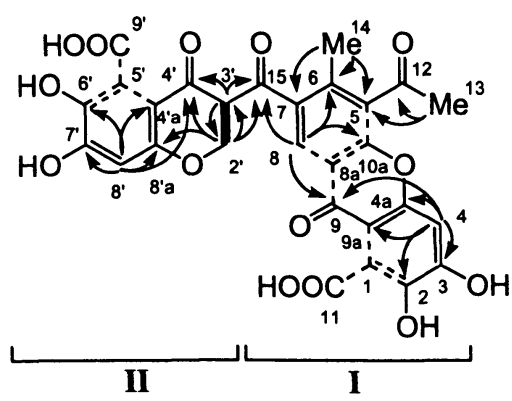

1b

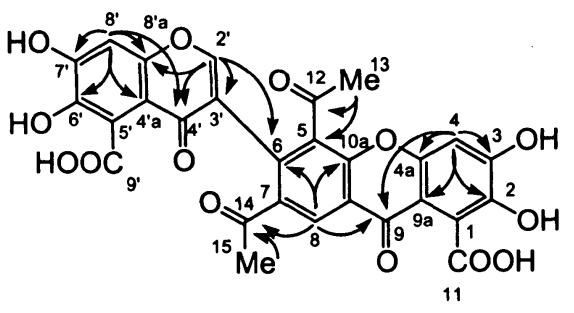

2 two hydrogen atoms. The UV spectrum and IR absorption bands (1620 and $1570 \mathrm{~cm}^{-1}$ for $\gamma$-pyrone) suggested the presence of a xanthone chromophore. The ${ }^{1} \mathrm{H}$ and ${ }^{13} \mathrm{C}$ NMR spectral data of $\mathbf{1}$ in comparison with $\mathbf{2}$ are summarized in Table 2. These NMR spectral data indicated that $\mathbf{1}$ existed as a mixture of two tautomers $\mathbf{1 a}$ and $\mathbf{1 b}$ in DMSO- $d_{6}$, with 1a being the preferred form. The ratio was approximately $4: 1$ by the integration value in the ${ }^{1} \mathrm{H}$ NMR spectrum.

The ${ }^{1} \mathrm{H}$ and ${ }^{13} \mathrm{C}$ NMR spectra of $\mathbf{1 b}$ were very similar to those of 2, except that $\mathbf{1 b}$ showed signals for a methine group (C-3'; $\left.\delta_{\mathrm{H}} 5.02, \delta_{\mathrm{C}} 56.2\right)$ and a methylene group (C$\left.2^{\prime} ; \delta_{\mathrm{H}} 4.61,4.71, \delta_{\mathrm{C}} 68.0\right)$ in place of one of the aromatic methine groups and one of the quaternary carbons observed in 2. Analysis of the COSY and HMBC spectra of $\mathbf{1 b}$ revealed two partial structures I and II (Fig. 4). The partial structure I was assigned on the basis of ${ }^{1} \mathrm{H}$ and ${ }^{13} \mathrm{C}$ chemical shifts and the HMBC correlations analogous to those observed for the two aromatic protons at $\mathrm{H}-4$ and $\mathrm{H}-8$ in 2. The aryl methyl group $\left(\delta_{\mathrm{H}} 2.28, \delta_{\mathrm{C}} 17.0\right)$ was located at $\mathrm{C}-6$ on the basis of the $\mathrm{HMBC}$ correlations of $\mathrm{H}_{3}-14$ with C-5, C-6 and C-7 and of H-8 with C-6. The HMBC correlations of $\mathrm{H}_{3}-13$ with $\mathrm{C}-5$ and $\mathrm{C}-12$ and of $\mathrm{H}-8$ with $\mathrm{C}-15$ placed the ketone carbon $\left(\mathrm{C}-15 ; \delta_{\mathrm{C}} 199.1\right)$ at the ortho position to $\mathrm{H}\lrcorner 8$ and the aryl methyl group at the ortho position to both the acetyl group and C-15. The partial structure II was identified through the proton spin network of $\mathrm{H}_{2}-2^{\prime}\left(\delta_{\mathrm{H}} 4.61,4.71\right)$ and $\mathrm{H}-3^{\prime}\left(\delta_{\mathrm{H}} 5.02\right)$ and $\mathrm{HMBC}$ correlations of $\mathrm{H}-8^{\prime}$ with $\mathrm{C}-4^{\prime} \mathrm{a}, \mathrm{C}-6^{\prime}, \mathrm{C}-7^{\prime}, \mathrm{C}-8^{\prime} \mathrm{a}$ and $\mathrm{C}-4^{\prime}$ (four-bond coupling) and of $\mathrm{H}_{2}-2^{\prime}\left(\delta_{\mathrm{H}} 4.61,4.71\right)$ with $\mathrm{C}-3^{\prime}, \mathrm{C}-4^{\prime}$ and $\mathrm{C}-8^{\prime} \mathrm{a}$ and of $\mathrm{H}-3^{\prime}\left(\delta_{\mathrm{H}} 5.02\right)$ with $\mathrm{C}-2^{\prime}$ and $\mathrm{C}-4^{\prime}$. The cross peaks from $\mathrm{H}-2^{\prime}$ and $\mathrm{H}-3^{\prime}$ to the ketone carbon $\left(\mathrm{C}-15 ; \delta_{\mathrm{C}} 199.1\right)$ indicated the connection of $\mathrm{C}-3^{\prime}$ in the partial structure II to $\mathrm{C}-15$ in the partial structure $\mathbf{I}$. The assignments of remaining three quaternary carbons $(\mathrm{C}-1$, C-8a and $\left.\mathrm{C}-5^{\prime}\right)$ and two carboxyl carbons (C-11 and C-9') were established by comparing the ${ }^{13} \mathrm{C}$ NMR chemical shifts with those of $\mathbf{2}$. Taken together, the structure of $\mathbf{1 b}$ was determined as shown in Fig. 4.

The ${ }^{1} \mathrm{H}$ and ${ }^{13} \mathrm{C}$ NMR spectra and HMBC correlations of 1a were almost identical to $\mathbf{1 b}$, but significant differences in chemical shift were observed at C-15 (1b: $199.1 \mathrm{ppm} ; \mathbf{1 a}$ : 172.7 ppm), C-3' (1b: 56.2 ppm; 1a: 104.2 ppm) and H-3' (1b: $5.02 \mathrm{ppm}$; 1a: absent). These data indicated that the 1,3-diketone moiety in $\mathbf{1 b}$ was enolized in $\mathbf{1 a}$. The ${ }^{13} \mathrm{C}$ NMR chemical shifts for C-15 $\left(\delta_{\mathrm{C}} 172.7\right)$ and C-4' $\left(\delta_{\mathrm{C}}\right.$ 183.7) and the HMBC correlations of $\mathrm{H}-8$ with $\mathrm{C}-15$ and of $\mathrm{H}-8^{\prime}$ with $\mathrm{C}-4^{\prime}$ revealed that 1 a was enolized at $\mathrm{C}-15$, not C-4'. Thus 1a was determined to be the 15-enolized tautomer of $\mathbf{1 b}$.

\section{Semaphorin Inhibitory Activity}

To evaluate semaphorin inhibitory activity, semaphorininduced growth cone collapse assay was employed. Compounds 1 and 2 inhibited Sema3A-induced growth cone collapse dose-dependently (Fig. 5). The $\mathrm{IC}_{50}$ values were 0.09 and $0.1 \mu \mathrm{g} / \mathrm{ml}$, respectively. In control experiments in the absence of Sema3A, they exhibited no adverse effect on the morphology of DRG cells. These indicate that the two compounds are potent and specific semaphorin inhibitors. 
Fig. 5. Inhibition of Sema3A-induced growth cone collapse by xanthofulvin (1) and vinaxanthone (2).

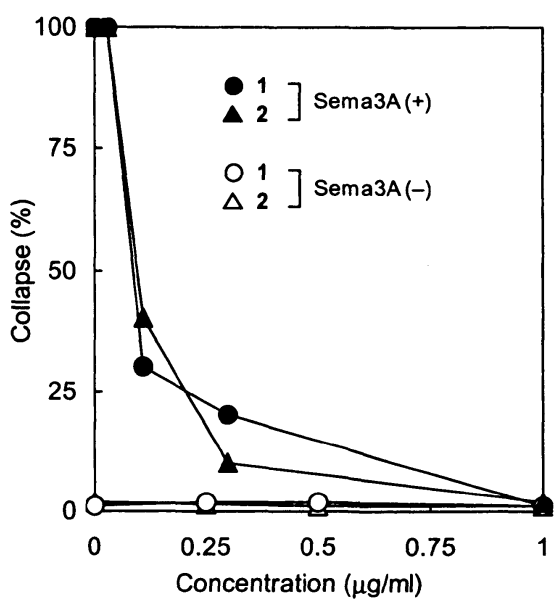

Discussion

We have isolated $\mathbf{1}$ and $\mathbf{2}$ from the cultured broth of Penicillium sp. SPF-3059 as semaphorin inhibitors. Recently several protein kinase inhibitors such 'as lavendustin $\mathrm{A}$ and olomoucine have been reported to have semaphorin inhibitory activity ${ }^{13,14)}$. Compounds $\mathbf{1}$ and $\mathbf{2}$ are structurally unrelated to these compounds.

The structure of compound $\mathbf{1}$ was established as a new compound xanthofulvin. However, xanthofulvin was first discovered by MASUBUCHI et al. from a strain of Eupenicillium as a chitin synthase II inhibitor $\left(\mathrm{IC}_{50} 2.2 \mu \mathrm{M}\right)$ as appeared in a patent literature ${ }^{15}$. Compound 2 has been previously isolated from Penicillium spp. as inhibitors of phospholipase $\left.\mathrm{C}\left(\mathrm{IC}_{50} 5.4 \sim 44 \mu \mathrm{M}\right)^{6}\right)$, CD4-anti-Leu3a binding $\left(\mathrm{IC}_{50} 2 \mu \mathrm{M}\right), \mathrm{CD} 4-\mathrm{MHC}$ class $\mathrm{II}$ binding ( $\mathrm{IC}_{50}$ $1 \mu \mathrm{M})$ and antigen-induced CD4-dependent $\mathrm{T}$ cell proliferation $\left(\mathrm{IC}_{50} 1 \sim 10 \mu \mathrm{M}\right)^{16)}$. Compared with these reported activities, semaphorin inhibitory activity we report here is sub- $\mu \mathrm{M}$ range and stronger by several tens-fold. Detailed evaluation of semaphorin inhibitory activity of $\mathbf{1}$ in vitro and in vivo as well as its mechanism of action will be reported elsewhere ${ }^{12)}$.

\section{References}

1) Pasterkamp, R. J. \& J. Verhaagen: Emerging roles for semaphorins in neural regeneration. Brain Res. Rev. 35: 36 54, 2001

2) Bamberg, J. R.; S. Baumgartner, H. Betz, J. Bolz, A. Chedotal, C. R. L. Christensen, P. M. Comoglio, J. G.
Culotti, P. Doherty, H. Drabkin, A. Ensser, M. C. Fishman, B. Flecken-Stein, G. J. Freeman, H. Fujisawa, A. Ghosh, D. D. Ginty, C. S. Goodman, S. Guthrie, S. Inagake, R. Keynes, T. Kimura, M. Klagsbrun, A. L. Kolodkin, J. Y. Kuwada, Y. Luo, J. D. Minna, S. L. Naylor, T. P. O'Connor, D. D. M. O'Leary, A. Pinl, M.-M. Poo, A. W. Puschel, J. A. Raper, J. Roche, C. J. Shatz, W. D. Snider, E. Soriano, M. K. Spriggs, S. M. Stritt-Matter, S. Sullvan, L. Tamagnone, M. Tessier-Lavigne, T. Tohyama, J. VerhaAgen, F. S. Walsh \& T. Yagi: Unified nomenclature for the semaphorins/collapsins. Cell 97: $551 \sim 552,1999$

3) LuO, Y.; D. Raible \& J. A. Raper: Collapsin: a protein in brain that induces the collapse and paralysis of neuronal growth cones. Cell 75: 217 227, 1993

4) Taniguchi, M.; S. Yuasa, H. Fujisawa, I. Naruse, S. SAGA, M. Mishina \& T. YAGI: Disruption of semaphorin III/D gene causes severe abnormality in peripheral nerve projection. Neuron 19: 519 530, 1997

5) Pasterkamp, R. J.; R. J. Giger, M. J. Ruitenberg, A. J. Holt-MaAt, J. D. Wit, F. D. Winter \& J. VerhaAgen: Expression of the gene encoding the chemorepellent semaphorin III is induced in the fibroblast component of neural scar tissue formed following injuries of adult but not neonatal CNS. Mol. Cell. Neurosci. 13: 143 166, 1999

6) AoKi M.; Y. Itezono, H. Shirai, N. Nakayama, A. Sakai, Y. Tanaka, A. Yamaguchi, N. Shimma, K. YoKOSE \& H. SETO: Structure of a novel phospholipase C inhibitor, vinaxanthone (Ro 09-1450), produced by Penicillium vinaceum. Tetrahedron Lett. 32: 4737 4740, 1991

7) Wrigley, S. K.; M. A. Latif, T. M. Gibson, M. I. Chicarelli-Robinson \& D. H. Williams: Structure elucidation of xanthone derivatives with CD4-binding activity from Penicillium glabrum (Wehmer) Westling. Pure \& Appl. Chem. 66: 2383 2386, 1994

8) PITT, J. I.: The genus Penicillium and its teleomorphic states Eupenicillium and Talaromyces. Academic Press, New York, 1979

9) Nippon Shikisai Kenkyuusyo (Ed.): Color Tone Manual. Nippon Shikiken Jigyo Co., Tokyo, 1973

10) Puschel, A. W.; R. H. Adams \& H. Betz: Murine semaphorin $\mathrm{D} /$ collapsin is a member of a diverse gene family and creates domains inhibitory for axonal extension. Neuron 14: 941 948, 1995

11) Shimamoto, A.; T. Kimura, K. Matsumoto \& $T$. NAKAMURA: Hepatocyte growth factor-like protein is identical to macrophage stimulating protein. FEBS Lett. 333: $61 \sim 66,1993$

12) KikUChi, K.; A. Kishino, O. Konishi, K. Kumagai, N. Hosotani, I. SAJi, C. NaKayama \& T. KimUra: In vitro and in vivo characterization of a novel semaphorin $3 \mathrm{~A}$ inhibitor, SM-216289 or xanthofulvin. J. Biol. Chem. submitted

13) Sasaki, Y.; C. Cheng, Y. Uchida, O. NaKajima, T. Ohshima, T. Yagi, M. Taniguchi, T. Nakayama, R. Kishida, Y. Kudo, S. Ohno, F. NaKamura \& Y. Goshima: Fyn and Cdk5 mediate semaphorin-3A signaling, which is involved in regulation of dendrite orientation in cerebral cortex. Neuron 35: 907 920, 2002 
14) Eickholt, B. J.; F. S. WAlsh \& P. Doherty: An inactive pool of GSK-3 at the leading edge of growth cones is implicated in Semaphorin 3A signaling. J. Cell Biol. 157: $211 \sim 217,2002$

15) Masubuchi, M.; T. OKuda \& H. Shimada (F. HoffmannLa Roche, AG): Antifungal agent xanthofulvin and its manufacture with Eupenicillium. EP 0537622, Apr. 21, 1993
16) Gammon, G.; G. Chandler, P. Depledge, C. Elcock, S. Wrigley, J. Moore, G. Cammarota, F. Sinigaglia \& M. MOORE: A fungal metabolite which inhibits the interaction of CD4 with major histocompatibility complex-encoded class II molecules. Eur. J. Immunol. 24: 991 998, 1994 